\title{
Development of Optimized Perforated Area Based MA Packages for Tomatoes and Guava
}

\author{
S Mangaraj* \\ ICAR-Central Institute of Agricultural Engineering, India
}

Submission: August 31, 2017; Published: October 25, 2017

*Corresponding author: S Mangaraj, Principal Scientist, Centre of Excellence on Soybean Processing and Utilization, ICAR-Central Institute of Agricultural Engineering, Madhya Pradesh, India, Email: sukhdev0108@gmail.com

\begin{abstract}
For retail size MA package, optimized the area of $\%$ perforation (guava- $0.0019 \%$ and tomatoes- $0.0040 \%$ ) for achieving the recommended level of gas composition for prolonged storage of guava and tomatoes. Storage study of guava and tomatoes in retail size MA packaging reveled that tomatoes in perforated package can be stored up to 28 days and 45 days and guava up to 9 days and 20 days at 25 and $10^{\circ} \mathrm{C}$, respectively. This technology solved the constraints of non-availability of perm selective films for fresh produce packaging applications with low cost and simplicity in performance to enhance the shelf life of commodities.
\end{abstract}

\section{Introduction}

MA packaging of fresh produce constitutes a dynamic system during which the gas transmission through the polymeric films and respiration of the fresh produce takes place simultaneously. The design of MA packaging is highly important to achieve the desired dynamic gas equilibrium condition to maintain quality and extend shelf life of the products [1-3]. The main constraints in MA packaging is that most of the films available for packaging does not meet the permeability requirement of the MA packaging of fresh produce. There are many options like active packaging using different sachets, gas flushing, development of oxygen tailored films which involves additional infrastructures/facilities, cost and skills. Whereas as the MA packaging system has been considered advantageous to other techniques because it involves low cost and simplicity in operations to enhance the shelf life of commodities especially for developing country like India [4,5]. Hence for retail size MA packaging of tomatoes and guava, the area of perforations was optimized for gas transmission so that the desired level of oxygen and carbon dioxide concentrations are achieved during the storage periods to reduce the overall metabolic processes and maintain quality for longer period [6-8].

\section{Materials and Methods}

The package size of $25 \times 22 \mathrm{~cm}$ and $18 \times 16 \mathrm{~cm}$ having fill weight of $1 \mathrm{~kg}$ was found suitable for MA packaging of tomatoes and guava, respectively using $60 \mu$ (LDPE+LLDPE) plastic films. To attain the required gas compositions inside the modified atmosphere packages, the area of perforation was varied from $0.0010-0.0070 \%$ using $0.45 \mathrm{~mm}$ needle. The MA packages were kept for storage study at ambient $\left(25{ }^{\circ} \mathrm{C}\right.$ ) and $10{ }^{\circ} \mathrm{C}$ (Figure 1) and the quality parameters were measured at regular intervals.

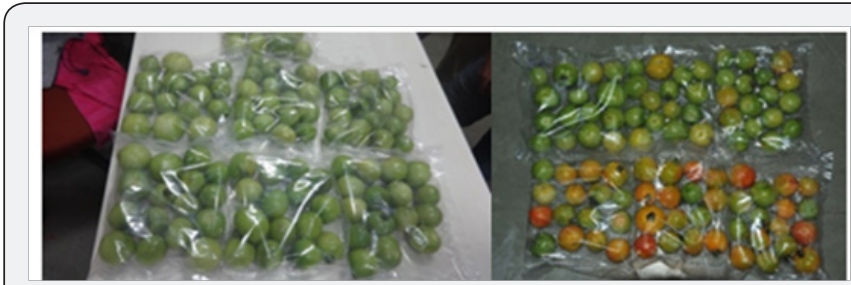

Figure 1: MAP with optimized area of perforation at 0 days and 28 days.

Developed a retail size MA packages for tomatoes and guava, with optimized area of perforations for gas transmission so that the desired level of oxygen and carbon dioxide concentrations are achieved during the storage periods to reduce the overall metabolic processes and maintain quality for longer period. The package size of $25 \times 22 \mathrm{~cm}$ and $18 \times 16 \mathrm{~cm}$ having fill weight of $1 \mathrm{~kg}$ was found suitable for MA packaging of tomatoes and guava, respectively using $60 \mu$ (LDPE+ LLDPE) plastic films. To attain the required gas compositions inside the MAP, the area of perforation was varied from 0.0010-0.0070\%.

\section{Results and Discussions}

MA packages having perforation area of $0.001 \%, 0.0019 \%$, $0.0032 \%, 0.0040 \%, 0.0051 \%, 0.0063 \%$, and $0.0073 \%$ attained 
the final gas composition of 02 and $\mathrm{CO} 2$ as $1.8,11.00 ; 4.5,6.2$; $7.4,6.1 ; 11.3,5.5 ; 13.4,5.3 ; 15.6,4.8$ and $17.8,2.1$, respectively. Hence it was found that $0.0019 \%$ area of perforation maintained the required gas concentration of $4.5 \%$ oxygen and $6.2 \%$ carbon dioxide inside the package during storage. The perforation areas of $0.0019-0.0070 \%$ MA packages were successful in maintaining the quality of the tomatoes. However the best quality was maintained in MA package of $0.0019 \%$ area of perforation up to 28 days and 45 days as compare to control and other perforated films at ambient and $10^{\circ} \mathrm{C}$ temperatures, respectively as shown in Table 1. Similar levels of perforations were done for MA packaged guava and storage study was carried out. It was found that $0.0040 \%$ area of perforation maintained the required gas concentration of 5.1 $\%$ oxygen and $4.2 \%$ carbon dioxide inside the package during the storage. All the packages except 0.001 and $0.0019 \%$ area of perforation maintained the quality of guava but best quality was maintained at $0.004 \%$ area perforated MA packaging ( $\mathrm{a}^{*}=$ -4.3 , firmness $=170.36$, PWL $(\%)=1.25)$ as compared to control sample as shown in Table 2. This package maintained the quality of guava up to 8-9 days and 20 days at ambient $\left(25^{\circ} \mathrm{C}\right)$ and $10^{\circ} \mathrm{C}$, respectively as shown in Figure 1 . Similar results were found by Mangaraj et al. [3] Babitha \& Kiranmayi [9], Arazuri et al. [10].

Table 1: Variations in quality parameters of tomatoes in perforated MA Packages.

\begin{tabular}{|c|c|c|c|c|c|c|c|c|c|c|c|c|}
\hline \multirow{2}{*}{$\begin{array}{c}\text { Perforated } \\
\text { area in MAP }\end{array}$} & \multicolumn{3}{|c|}{$\mathbf{a}^{*}$} & \multicolumn{3}{|c|}{ Firmness (N) } & \multicolumn{3}{|c|}{ PLW (\%) } & \multicolumn{3}{|c|}{ TSS } \\
\hline & 0 days & $\begin{array}{l}28 \text { days } \\
\text { at } 25^{\circ} \mathrm{C}\end{array}$ & $\begin{array}{l}\text { 45days } \\
\text { at } 10^{\circ} \mathrm{C}\end{array}$ & 0 days & $\begin{array}{l}28 \text { days } \\
\text { at } 25 \stackrel{\circ}{ } \mathrm{C}\end{array}$ & $\begin{array}{l}\text { 45days } \\
\text { at } 10^{\circ} \mathrm{C}\end{array}$ & $\begin{array}{c}0 \\
\text { days }\end{array}$ & $\begin{array}{l}28 \text { days } \\
\text { at } 25^{\circ} \mathrm{C}\end{array}$ & $\begin{array}{l}\text { 45days } \\
\text { at } 10{ }^{\circ} \mathrm{C}\end{array}$ & 0 days & $\begin{array}{l}28 \text { days } \\
\text { at } 25^{\circ} \mathrm{C}\end{array}$ & $\begin{array}{l}\text { 45days } \\
\text { at } 10 \circ \mathrm{C}\end{array}$ \\
\hline P2 & -10.93 & -5.67 & -4.34 & 100.69 & 72.13 & 69.14 & 0 & 1.7 & 1.7 & 3.9 & 4.5 & 4.8 \\
\hline P3 & -10.93 & -3.24 & -2.13 & 100.69 & 65.67 & 63.56 & 0 & 1.7 & 1.8 & 3.9 & 4.5 & 4.8 \\
\hline P4 & -10.93 & -2.95 & 1.23 & 100.69 & 62.13 & 59.1 & 0 & 1.8 & 1.8 & 3.9 & 4.6 & 4.8 \\
\hline P5 & -10.93 & 4.35 & 5.45 & 100.69 & 61.02 & 57.43 & 0 & 1.9 & 1.9 & 3.9 & 4.7 & 4.9 \\
\hline P6 & -10.93 & 9.03 & 13.42 & 100.69 & 58.34 & 55.61 & 0 & 2 & 1.9 & 3.9 & 4.7 & 4.9 \\
\hline P7 & -10.93 & 15.06 & 18.9 & 100.69 & 55.97 & 53.14 & 0 & 2.1 & 2.1 & 3.9 & 4.8 & 5 \\
\hline CS & -10.93 & & & 100.69 & & & 0 & & & 3.9 & & \\
\hline
\end{tabular}

Table 2: Variations in quality parameters of guava in perforated MA Packages

\begin{tabular}{|c|c|c|c|c|c|c|c|c|c|c|c|c|}
\hline \multirow[b]{2}{*}{$\begin{array}{c}\text { Perforated } \\
\text { area in MAP }\end{array}$} & \multicolumn{3}{|c|}{$a^{*}$} & \multicolumn{3}{|c|}{ Firmness (N) } & \multicolumn{3}{|c|}{ PLW (\%) } & \multicolumn{3}{|c|}{ TSS } \\
\hline & 0 days & $\begin{array}{l}09 \text { days } \\
\text { at } 25^{\circ} \mathrm{C}\end{array}$ & $\begin{array}{c}20 \\
\text { days at } \\
10^{\circ} \mathrm{C}\end{array}$ & 0 days & $\begin{array}{l}09 \text { days } \\
\text { at } 25 \stackrel{\circ}{ } \mathrm{C}\end{array}$ & $\begin{array}{l}20 \text { days } \\
\text { at } 10^{\circ} \mathrm{C}\end{array}$ & 0 days & $\begin{array}{l}09 \text { days } \\
\text { at } 25^{\circ} \mathrm{C}\end{array}$ & $\begin{array}{l}20 \text { days } \\
\text { at } 10^{\circ} \mathrm{C}\end{array}$ & 0 days & $\begin{array}{l}09 \text { days } \\
\text { at } 25^{\circ} \mathrm{C}\end{array}$ & $\begin{array}{l}20 \text { days } \\
\text { at } 10^{\circ} \mathrm{C}\end{array}$ \\
\hline P3 & -18.9 & -4.34 & -3.34 & 298.13 & 220.45 & 167.34 & 0 & 1.25 & 1.45 & 9.2 & 10 & 10.4 \\
\hline $\mathrm{P} 4$ & -18.9 & -3.31 & -2.21 & 298.13 & 201.28 & 155.34 & 0 & 1.26 & 1.46 & 9.2 & 10.1 & 10.5 \\
\hline P5 & -18.9 & -2.65 & -1.98 & 298.13 & 194.56 & 125.44 & 0 & 1.25 & 1.47 & 9.2 & 10.2 & 10.5 \\
\hline P6 & -18.9 & 2.12 & 3.89 & 298.13 & 184.56 & 120.45 & 0 & 1.26 & 1.5 & 9.2 & 10.4 & 10.6 \\
\hline P7 & -18.9 & 5.21 & 6.71 & 298.13 & 174.9 & 115.62 & 0 & 1.23 & 1.52 & 9.2 & 10.4 & 110.7 \\
\hline CS & -18.9 & & & 298.13 & 57.21 & & 0 & & & 9.2 & & \\
\hline
\end{tabular}

\section{References}

1. Kader AA, Zagory D, Kerbel EL (1989) Modified atmosphere packaging of fruits and vegetables. Crit Rev Food Sci Nutr 28(1): 1-30.

2. Mangaraj S, Sadawat IJ, Prasad S (2011) Assessment of quality of pears stored under laminated modified atmosphere packages. International journal of Food Properties 14(5): 1110-1123.

3. Mangaraj S, Goswami TK, Giri SK, Joshy CG (2014) Design and develoepeemnt of a modified atmosphere packaging system for guava (cv. Baruipur). Journal of Food Science and Technology 51(11): 29252946.

4. Mangaraj S, Goswami TK, Mahajan PV (2009) Application of plastic films in modified atmosphere packaging of fruits and vegetables - A review. Food Engineering reviews 1: 133-158.

5. Mangaraj S, Goswami TK, Giri SK, Tripathi MK (2012) Permselective MA packaging of litchi (cv. Shahi) for preserving quality and extension of shelf-life. Postharvest Biology and Technology 71: 1-12.
6. Mangaraj S, Goswami TK (2009) Modified atmosphere packaging An ideal food preservation technique. Journal of Food Science and Technology, 46(5): 399-410.

7. Mangaraj S, Goswami TK (2011a) Modelling of respiration rates of litchi fruit under aerobic condition. Food and Bioprocess Technology. An international Journal 4: 272-281.

8. Mangaraj S, Goswami TK (2011b) Measurement and modelling of respirtion rates of guava (cv. Baruipur) for modfied atmosphere packaging. International journal of Food Properties 14(3): 609-628.

9. Babitha B, Kiranmayi P (2010) Effect of Storage Conditions on the Post-Harvest Quality of Tomato (Lycopersiconesculentum). Res J Agric Sc 1(4): 409-411.

10. Arazuri S, Jare'n C, Arana JI, Pe'rez de Ciriza JJ (2007) Influence of mechanical harvest on the physical properties of processing tomato (Lycopersiconesculentum Mill). Journal of Food Engineering 80: 190198. 
This work is licensed under Creative Commons Attribution 4.0 License

DOI:10.19080/NFSIJ.2017.03.555618
Your next submission with Juniper Publishers will reach you the below assets

- Quality Editorial service

- Swift Peer Review

- Reprints availability

- E-prints Service

- Manuscript Podcast for convenient understanding

- Global attainment for your research

- Manuscript accessibility in different formats

( Pdf, E-pub, Full Text, Audio)

- Unceasing customer service

Track the below URL for one-step submission https://juniperpublishers.com/online-submission.php 